\title{
Mineral Resource Extractive Activities in Nigeria: Communities Also Matter!
}

\author{
Ali I. Naibbi ${ }^{*}$, Murtala Chindo ${ }^{2}$ \\ ${ }^{1}$ Department of Geography, Yusuf Maitama Sule University, Kano, Nigeria \\ ${ }^{2}$ Department of Geography, Ibrahim Badamasi Babangida University, Lapai, Nigeria \\ Email: *sarkinaibbi@gmail.com, murtalachindo@gmail.com
}

How to cite this paper: Naibbi, A. I., \& Chindo, M. (2020). Mineral Resource Extractive Activities in Nigeria: Communities Also Matter! Journal of Geoscience and Environment Protection, 8, 212-229. https://doi.org/10.4236/gep.2020.89013

Received: April 14, 2020

Accepted: September 27, 2020

Published: September 30, 2020

Copyright () 2020 by author(s) and Scientific Research Publishing Inc. This work is licensed under the Creative Commons Attribution International License (CC BY 4.0).

http://creativecommons.org/licenses/by/4.0/

(c) (i) Open Access

\begin{abstract}
Poor management of land resources creates environmental problems such as land degradation, soil erosion and pollution, as well as serious social and economic tensions. Mineral extraction, production, refining and distribution have immediate impact on the environments and their host communities. Nigeria being an extractive economy with numerous cases of defiance by the host communities on the mining operating companies, a number of ways for advancing dealings with communities can be drawn to inform broader community dialogue in the extractive economy of Nigeria and countries with similar situations. This paper used information from secondary sources to demonstrate the importance of accommodating host communities as stakeholders. The paper establishes the various roles played by mining stakeholders and how their involvements have changed overtime in terms of scale. Options were drawn for improving the current state of Nigerian mining communities and suggestions were made on avoiding future host community conflict (typically existing in the oil region of the country). The paper recommends that the recognition of communities as stakeholders is crucial in developing Nigeria's non-oil sector.
\end{abstract}

\section{Keywords}

Mineral, Mining, Communities, Stakeholders, Nigeria

\section{Introduction}

As Nigeria is rapidly increasing its investment opportunities in resource wealth, greater access to the country is leading to increased resource extraction activities, particularly non-oil mining across the country. While oil and gas industries and solid minerals provide significant economic opportunities for the country's eco- 
nomic prosperity, there are also costs (social, environmental and human) associated with these activities that must not be ignored. These costs are prevalent and widespread in the local communities. However, the state of today's communities impacted by extractive activities is heavily influenced by governments and companies (Franks et al., 2014). The oil and gas sector has, however, been the most challenging, as oil companies are in constant conflict with the communities, and the communities are in grievances with the government and companies (Kemp et al., 2011; Koos \& Pierskalla, 2016). For example, in Nigeria, while crisis still lingers in the oil producing Niger Delta, new developments in the non-oil sector are showing signs of the Niger Delta struggles. Already, the brunt borne by communities through extensive mining is a terrain of discursive and material contestation since community members perceived mining operations as a form of external suppression-a scenario where the government is imagined as having the cake and the communities seeing themselves as being denied of their fair share. The nexus between rapid increase in extractive industries and communities have earlier been suggested-see for example the work of Maconachie and Hilson (2013: p. 347), as follows:

"While resource extractive investment has had significant social, political and economic implications for actors at all scales... the livelihood impacts of intensified resource extraction at the community-level have been particularly varied and profound. At the community level, responses to heightened investment in the extractive industries have been wide ranging: variously met by resistance and rejection, by acquiescence combined with demands for better labour conditions and community benefits, and in other cases, outright acceptance in anticipation of gainful employment and expectations of "modernization".

Based on the dynamic nature of communities in the midst of increasing extractive activities highlighted by Maconachie and Hilson (2013), this paper provides a narrative to stimulate new line of discourse and policy direction around the present day mining communities in Nigeria. The premise of the paper is based on the assertion that importance must be given to communities in mineral development, especially in resource rich (but resource cursed-see for example, Al-Abri et al., 2019) countries like Nigeria. Given Nigeria's reprehensible reputation with oil-producing communities (see, for example, Auty, 1993; Watts, 2004a, 2004b, 2008; United Nations Development Programme (UNDP), 2006; Ogunleye, 2008; Amnesty International, 2009; United Nations Environmental Programme (UNEP), 2011; Koos \& Pierskalla, 2016; Albert et al., 2019), non-oil industries that are investing in the country could draw lessons from the Niger Delta, and other parts of the world, to avoid replicating the debilitating negativity attached to resource production.

\section{Concepts and Methods}

For the purpose of this paper, minerals are taken to be what are known in the 
business as "hard/solid minerals" (Humphreys, 2013), although reference is made along the way to other mineral products including oil and gas. For communities-the concept is highly contested, imprecise and even policy dependent (see, for example, Kapelus, 2002; Li et al., 2012). The term is defined in terms of the following approaches; by association and impact (see Veiga et al., 2001; Cheney et al., 2002), by geographic and homogenous terms (see, for example, Accountability and Business for Social Responsibility (BSR), 2004; Luning, 2012), or by best practice (see for example, International Finance Corporation (IFC), 2000, 2007; International Institute of Environment and Development (IIED), 2002). Because of these wide ranging approaches, communities in this paper refers to a socially, culturally and ecologically bounded group of people whose location is close to, or downstream from an extractive activity operation, and are affected by such operation, and hold the right to make decisions based on perceived mutual benefit of its members.

This paper gathered and synthesised as much information as possible from different secondary sources such as; academic and grey literature, which provided significant amount of information on the subject matter, and from media reports because of their enormous influence in shaping public opinion, policy, and personal experience of the authors. Overall, the documents used here were selected based on their merits. The paper is structured as follows. Section 2 explores why communities should be recognised as stakeholders and the role of government as a stakeholder respectively. Section 3 examines the emergence and evolutionary trends of communities within the Nigerian extractive economy. Section 4 illustrates the policy implications and the way forward for communities hosting extractive activities respectively.

\section{Communities as Stakeholders}

There is a huge literature on mining and stakeholders which this paper has not reported, because the focus here is on understanding the position of communities as key stakeholders in extractive industries. Freeman (1984: p. 84) states that "a stakeholder in an organisation is any group or individual who can affect or is affected by the achievement of the organisation's objectives". Subsequently, a number of writers have contributed to the stakeholder debate (see, for example, Donaldson \& Preston, 1995; Clarkson, 1995; Östensson, 1997; Phillips \& Reichart, 2000; Matu et al., 2020). For example, Östensson (1997), viewed stakeholders in mining as "somebody, or a group of some bodies, who has an interest, be it economic, legal, political or ethical, in the outcome of a project or a process, and who therefore holds a stake in it". By this view, any individual or group who affect or are being affected by mineral extraction in the past, present or in the future can be considered as a stakeholder. In view of the nature of mining, stakeholder involvement and the role they play is a dynamic process where some stakeholders may disengage over time, and others may join at a later stage of the project. 
Östensson (1997) divided stakeholders into primary (core) and secondary (peripheral). The "core stakeholders" are those who are materially affected by individual mining projects and whose objectives with respect to sustainable development relate mainly to those projects. This set the case for government (the regulator), local communities (host; including indigenous people and migrant workers) and mining companies (operator) themselves. Conversely, the "peripheral stakeholders" are those whose objectives are generally of a broader political, ideological or cultural nature, for instance, NGOs and intergovernmental organisations (IGOs) (Östensson, 1997). Financiers, NGOs, contractors, shareholders, customers and insurers all fall under the peripheral stakeholders because they have the "capacity to mobilise public opinion in favour of, or in opposition to, a corporation's performance" (Clarkson, 1995: p. 107). This is obvious, particularly when issues arises that draws their attention such as, project finance, environmental degradation to agricultural and traditional lands and water, corruption and lack of transparency, inequitable revenue sharing, conflict and human rights violations etc.

In view of the nature of mineral business, this paper adopts Clarkson's (1995: pp. 106-107) and Östensson's (1997) typology that classify the government and communities as their most salient (definitive) stakeholders. Although this is a simple classification, they are contentious when mining communities vary in their perceptions and expectations of mineral development. This becomes more sensitive in cases where there are indigenous communities or vulnerable groups who may be unrepresented, and when there are gender issues in specific contexts. For example, First Nations people ${ }^{1}$, who now claim to be right holders, no longer accept being grouped into that body of people who were being provided an opportunity to comment or participate in mining projects at the discretion of governments. Therefore, stakeholder mapping in a mining project is not a finite process, and is likely to continue beyond the scoping phase and throughout exploration, construction, production, and ultimately closure and remediation. The role of stakeholders also depends on local conditions and global order or movement. Azapagic (2004) noted that identifying mining stakeholders is a prerequisite for enhancing mining's contribution to development, even though working out the boundaries of rights and responsibilities continued to be a challenge. Nonetheless, the International Council on Mining and Metals' (2012) document entitled "community development-toolkit", could be adopted in identifying the potential interest groups.

\section{The Role of Government as a Stakeholder}

While mineral extraction, production, refining and distribution have immediate impact on the environments and communities in which they operate, the role played by government permeates all facets of the operational, financial and managerial life of their operations. Generally, countries' mineral resources are treated

${ }^{1}$ The First Nations are Canadians recognised as the indigenous Aboriginal who are neither Inuit nor Métis. 
as national heritage (Haysom \& Kane, 2009; Al-Abri et al., 2019). For example, as a colonial legacy, Nigeria, South Africa, Indonesia, India and most of the developing nations, have constitutionally entrusted their mineral ownership to the state. Conversely, most of the developed countries like Canada, Australia and the United States are able to manage their resources through individual, provincial and national ownerships. However, the only difference between the developing and developed countries mode of operation is in the requirement for ensuring an optimum equilibrium and trade-offs between the sustainability of mining dependent communities and promoting economic growth. In this light, the tasks of government involves drawing up legislations, regulations and codes, institutions, continuous arbitration and conflict resolution that provides a platform for both domestic and foreign investors, while protecting and safeguarding the environment and communities. As mining often occur in locations that are home to poor and vulnerable people (Kemp, 2009), those affected need government protection of their right to livelihoods. In the case of failure, weak regulation or non-enforcement and monitoring of rules, the government is directly or indirectly responsible for meeting the costs of environmental mismanagement and rebellion from the affected communities (see for examples Muradian et al., 2003; Watts, 2004a, 2008; Albert et al., 2019; Albert et al., 2020).

Even though, communities enjoys positive benefits including technology transfer and training for local populations, access to wealth through revenues and royalties, employment, the provision and improvements in infrastructure (roads, schools, health centres, water and sanitation), such benefits are most often destroyed by the mining activities (Fonseca, 2004). A similar outcome was reported by Bridge (2008) who noted that the fear of negative consequences often triggers rejection and political opposition by locals who see themselves as the first to bear the negative impacts. These impacts depend upon the nature of the mining operation, the size of the project, and the type of mineral being extracted, the type of exploitation method and the life span, the nature and sensitivity of the surrounding's physical and social environment, and the effectiveness of planning, pollution prevention and mitigation and control techniques. However, it should be noted that minimising the risks associated with mining on communities is solely the responsibility of the government, through policies that are mostly included in the respective government's national mining regulations. For example, in Indonesia, the licence holder must plan for the community beyond the lifespan of the mine. Similarly, Peru, Argentina, Columbia, Philippines and Chile are all intermittently refining legislation or regulation to address social impacts. However, all these are yielding insignificant results in the developing countries. For example, in Latin America alone, out of 139 mining companies sampled in 15 countries in 2010, 118 of them are in conflict with different communities (International Union for Conservation of Nature, 2010). Also, in some African countries like Nigeria, Ghana and South Africa, where community relations are part of the mining permitting process, their respective governments are inadequately protecting the mining communities, which make them vulnerable lead- 
ing to so many kinds of conflicts (Kemp, 2009; Albert et al., 2020).

Eggert (2001) highlighted that mining industries are only able to create mineral wealth when government establishes a suitable framework for them to thrive. For mining companies to maximise profit, the creation of the resources must be in a manner consistent with local conditions and global best practices. However, it is not a best practice for mining projects to simply conform to government regulations without measuring whether those regulations either adequately protect the environment or meet international standards, but rather, they are also guilty of influencing government policy/legislation in their favour (Amare, 2019). Over the last two to three decades, the ground rules for mineral projects have shifted significantly. The government's role in mining is now changing from an owner to a regulator, and the civil societies expect environmental responsibility and good relationship with local communities. Such policy shifts now puts more pressure on the mining operators, and compel them to obtain a "social licence" in order to operate-a means for local communities to be informed, participate, monitor and measure mining project life (see Veiga et al., 2001; Salim, 2003; Azapagic, 2004; Jenkins \& Yakovleve, 2006).

\section{Mineral Development and Communities in Nigeria}

There is a significant deposit of solid minerals in Nigeria (coal, oil sands, iron ore, gold, limestone, uranium, tantalum, diamond etc.) but the ascendancy of crude oil as a major income earner led to their neglect, where exploitation is poorly organised, lives of miners are gravely endangered, and the sector generates less revenue (Edeme \& Nkalu, 2019). In the last two decades, Nigeria like other resource rich countries has embarked on reforms in policies, institutions, fiscal and legal frameworks to revive the mineral sectors (Ishola, 2008; Edeme \& Nkalu, 2019). The country envisage for a national policy that encourage a shift in the role of government from "owner-operator" to "regulator-administrator", and that of the "private sector" as "operator" (Ministry of Mines and Steel Development, 2008). This implies that the role of government would now be limited to setting and monitoring operational guidelines, thus avoiding the skewed joint ventures that spawned revolt in the Niger Delta (see for example, Albert et al., 2020).

Nevertheless, Campbell (2012) noted the complexities of these changes in the developing countries. For example, the adoption of global initiatives such as the Extractive Industries Transparency Initiative (EITI) by Nigeria represents a significant acknowledgement of the importance of transparency and accountability for resource wealth. However, the Nigerian chapter of EITI, the Nigerian Extractive Industries Transparency Initiative (NEITI) constituted in 2007 majorly focussed on revenue generation to the government with little consideration to how corporate social responsibilities are being achieved.

In the past, records show that early mining in Nigeria was undertaken at specific sites in both small- and large-scale operations. For example, prior to colonial occupation, early European and Arab explorers, mainly Germans, Spanish and 
Lebanese, discovered, mined and traded tin, galena and gold with their home countries (Hodder, 1959). For example, tin was mined and smelted in the early eighteenth century (Fell, 1939; Hodder, 1959; National Bureau of Statistics, 2008). However, organised mining in Nigeria began between 1902 and 1923, following the commissioning of the minerals survey of the southern and northern protectorates (Marcellus, 2010). One interesting aspect of colonial mining was the recognition of Africans as occupiers of mineral-bearing land. Community leaders at that time were the recognised land owners and recipients of any compensation. As such, those individuals who owned that land where minerals were found hardly benefited. Also, mining employees (referred to as pagan labour), the majority of whom are unskilled and a few semi-skilled, had limited rights of negotiation, but were given certain protection by the Mining Regulation of 1927-1929. While colonial mining contributed to government revenues for infrastructural development at the national level, it relegated host communities from stakeholders to sources of labour. It is again obvious that before the enactment of the first Nigerian Mining Law in 1946, there was no documented environmental management strategy for mineral extraction, processing and reclamation (Usman, 2001).

In the country's first attempt at regulating mining activities, the 1946 Act included environmental protection. Yet, it has not changed mining-induced environmental degradation (Omotehinse \& Ako, 2019). For example, in support of Hodder (1959), the result of the various Nigerian government's survey in the last few decades has shown that the tin mines of Jos remain lethal pits, where about 1500 dangerous mining ponds from past mining have degraded the physical landscape (Vanguard, 2010; Goki et al., 2016; Omotehinse \& Ako, 2019). Also, the coal mines of Enugu have been partially converted into refuse dumps (Omotehinse \& Ako, 2019). Very recently, lead poisoning in Zamfara, Nigeria, led to the death of at least 500 children (see for example, Ibrahim \& Aliyu, 2010).

In view of the new Nigerian Mining and Minerals Act (NMMA) of 2007, Section 4.6.1, it is essential that mining grantee obtain consent from local authorities prior to the commencement of the development of mineral title. Also, the action plans entered into are documented as "Community Development Agreement" (CDA), which may include capacity building, education and employment in addition to social services and infrastructural development. While this policy may sound conventional, Chindo (2011: p. 46) reported that mining communities' consent is not even sought on the commencement of most mining projects. He posits that: "granted licences and permits commonly overlap other surface rights like private or public properties, forest reserves, conservation areas, farmlands and settlements, whilst, mineral exploration is prohibited in sacred areas and trees". Similarly, Chindo (2011) found significant overlap between granted mining licences and areas of high biodiversity and existing human settlement. For example, in 2010 alone, more than 1600 titles were issued in Nigeria. This poses a potential conflict between the need to access resources for development and the need to conserve biodiversity and livelihoods. Given Nigeria's horrific 
reputation in the oil sector, the development of non-oil sector must factor and take appropriately steps to mitigate any potential threat to the environment and local livelihoods, otherwise risks the trepidation of Niger Delta rebellion (Albert et al., 2020). While oil is localised in the Niger Delta region, solid minerals are found across different parts of the country. With the opening of a new mine (if not properly regulated), there is the potential for communities to be shattered, for environments to be destroyed and for carbon to be emitted. Likewise any potential conflict with communities is likely to be more widespread. In such situations, communities may suddenly end with abrupt dispersal of the population (Babatunde, 2012).

From the foregoing, it can be argued that the mining communities consultation in Nigeria have usually been superficial and grossly inadequate. Even though communities have been historically relevant in mining, their consideration and engagement as stakeholders is comparatively a new phenomenon. Host communities have been recently engaged as secondary stakeholders in the oil industry after many years of neglect by the Multinational Oil Corporations (MNOCs) and the Nigerian government. This was noted by Idemudia (2009: p. 2) who viewed host communities engagement as secondary stakeholders-instead of being primary stakeholders. Whereas the government has the capability of terminating mining operations, host communities do not have such a power, but have in recent times disrupted oil productions particularly in the Niger Delta region (Albert et al., 2020). For example, since the beginning of 2008, attention has now been given to the oil producing communities because they lay more threat to the oil operations (Albert et al., 2020). Conversely, some established cement companies like Dangote Group and Ibeto are countering civil society and community fears that resource extraction is "antidevelopment". These companies that are exploiting limestone and gypsum for cement production in North-central Nigeria are expanding their corporate services to include public participation, employment and business opportunities, contract awards and provision of infrastructure to their host communities. This kind of positive outlooks counters the oil sector's marginalisation of the Niger Delta (Albert et al., 2020).

The inability of government to provide basic human amenities to the host communities and protect them from environmental pollution by oil operations (Eweje, 2007) is a complete negation to Articles 1, 10, 18, 21 and 26 of the 2007 United Nations Declaration on the Rights of Indigenous Peoples. Due to lack of social infrastructure as a result of poor governance, Frynas (2005) added that oil companies are under pressure and threat by their host communities and Civil Societies to provide infrastructure in the Niger Delta. Supporting Frynas (2005), community investment deploys capital from investors and directs it to communities that are overlooked and underserved by their government. The communities, though sometimes ambivalent, are swayed toward mineral extraction for the money it will likely bring. In this instance, even at the initial stage of exploration, communities express optimism that extraction would lead to an improvement in the socio-economic life of their people. Such pragmatism is un- 
derstandable in the Niger Delta region, given the level of poverty in communities that are remote, deprived and seriously disadvantaged in terms of access to economic opportunities, social services, and infrastructure. In view of this kind of communities' dilemma, the Environmental Rights Action/Friends of the Earth Nigeria (ERA/FoEN) have prominently sensitised and empower communities to make informed choices about negotiating access to resource extraction. For instance, Ojo (2012) reported that the group is at the forefront in sensitising communities in Nigeria to use their bargaining power on planned bitumen exploration. This is against the fears that oil sands extraction has the following characteristics: 1) long-term (usually last up to 100 years depending on reserve, technology and economics); 2) complexity (usually involving heavy machinery, numerous parties, chain of investments, multiple partners and labour);3) capital intensive (requires massive investments of millions to billions of dollars); and 4) bad reputation (large-scale environmental impacts and displacement).

Overall, this paper argues that the sluggish nature of the Nigerian government towards managing antagonistic social issues should be rectified if at all the non-oil mining sector is to be developed and sustained. Otherwise, the government's efforts of expanding the extractive industry beyond oil extraction will be faced with the reoccurrence of the Niger Delta crises. For example, the Zamfara lead poison incidents in 2010 (Ibrahim \& Aliyu, 2010) and the records showing Nigeria as having one of the worst records of oil pollution of any oil producing country (United Nations Environmental Programme (UNEP), 2011) could expand the perception of the Nigerian government's weak institutional capacity to monitor and enforce mining regulations.

\section{Policy Implications}

It is important to note that communities are complex and at times difficult to predict, making common approach often untenable. Reflections on this section may assist in building dialogue and articulate shared features in order to escape from vulnerability to community opposition, which can result into additional financial and operational risks.

The NMMA 2007 intends to bring mining benefits to the local and national economy, but defining "host communities" has proven contentious, thus resulted in little discernible difference to the lingering crisis in the Niger Delta. A community under the existing definition consists of a selection of some few people as representatives who often see themselves as accountable to themselves, or to the chiefs and elders of their communities, as against accountability to all the stakeholders with interests in mining. This tend to accord the "landowners/chiefs" and "elites" (who are at the top of indigenous power hierarchies) special privileges and also craves a "hegemonic stake" in the communities. It is not uncommon that both international and national mining companies usually dialogue with these "local power centres", on the prospects of mineral extraction in their communities. While it is right to respect the local governance system and traditional institution, it is also a best practice to involve the majority of the 
community members that wants to participate irrespective of their social class. For example, there are unreported cases where the CDA composes only land owners and excluded women in decision making. This oversight has resulted in majority of the people of the local communities seeing themselves as being detached from mining in their domains, a situation that leads to apathy and even antagonism, if it remains unaddressed (Albert et al., 2020). As a consequence, it is now a common scene where community members that feel isolated by the glaring attention given to other groups could plot dangerous movement against the company as a way of drawing attention and for their voices to be heard (see for example, Ojo, 2012; Albert et al., 2020). When communities are identified and engaged at the earliest, Davis (1998) and Humphreys (2000, 2013) noted that it gives them sense of ownership of the process and are likely to support and participate in future community programmes.

Within the CDA provisions, there is need to articulate communities to agree with the mining procedure. Even if this was achieved, the question remains: Is the community where the mineral title area is located or the community closest to it that is regarded as the host community? If the latter, then there should be a defined perimeter for easy identification and management because mining is a localised activity that may have extensive spatial impacts. Thus, a buffer zone becomes necessary to make possible easy identification based on proximity and potential impacts. The same principle can be applied when it comes to compensation. Early stakeholder mapping in the scoping phase is a useful tool to allow stakeholders gain an appreciation of who is interested and how they may be involved, as well as identifying the nature of the interrelationships between stakeholder groups. Social analysis techniques (e.g. social network analysis or multi-stakeholder approach) can be used in identifying stakeholders, their needs, interactions, aspirations and concerns regarding the project. In identifying stakeholders, it is also advisable for mining companies to be as open and inclusive as possible. However, gauging opinion in a community of hundreds to thousands of people will be an inherently difficult task, if not essentially impossible. To overcome these challenging tasks, qualitative information gathering process can rely heavily on key informant opinion, that is, opinions of specific group of people considered to be representative of broader groups within the communities. To avoid the exclusion of significant groups, and for a more comprehensive assessment of situational context, considerable effort must be put into consulting community members representing different groups-such as neighbourhoods, gender, age, local NGOs and industry. This could enable an extensive contextualisation of variables that promote harmonious company-community-government relationship. Therefore, it is the position of this paper that the current usage of the concept of stakeholder when dealing with extractive resources especially in Nigeria needs to be redefined to include all the various groups within the community. This suggests that the various segments that make up the community are what really matters and any recognition must include them. For example, Jensen and Watchenko (2004) and Albert et al. (2020) suggested that the concen- 
tration of power among the few makes it rational for the opposition to pursue power through extra-constitutional means. These views have in part led to conflict and instability in the Niger Delta (Orogun, 2010; Watts, 2004a, 2004b, 2008; Albert et al., 2020).

Even if Nigeria is unwilling to pay rents and royalties from resource extraction to the host communities (see for example, Constitution of the Federal Republic of Nigeria, 1999: p. 28), this paper suggests that it should at least establish a transparent financial distribution system- "Communities Fund". The funds would assist the host communities to benefit directly from their mineral wealth apart from the normal minimal compensation paid for the land acquired for the purpose of mineral extraction. The Communities Fund may be generated from direct financial transfer of certain proportion of net profit (say up to 10 per cent or more) from Nigerian mineral tax and company income tax. Contributions made to the fund will be available as a credit against fiscal rent obligations being royalty, and that can be used for the provision of physical and social infrastructure, and for long-term investment in the host communities.

\section{Way Forward}

Even though, a feeling of relative deprivation was argued as the major source of grievance in the Niger Delta, this paper also supported Babatunde (2012: p. 51) who posits that oil-related activities have affected the people's livelihoods, food security, personal security, and physical and mental health. However, it should be remembered that ccurrently, the Nigerian oil producing communities receive 13 per cent of profits derived from petroleum sales otherwise known as the "13 per cent derivation fund". Instead of these funds serving as key drivers of economic growth and physical developments to the affected communities, it has left for instance, the actual oil and gas communities in abject poverty (Watts, 2008; Amnesty International, 2009). This could be attributed to the number of cases where states and local governments in the region illegally siphoned the money to fund other non-oil communities (or misappropriate them for their personal gains), leaving the actual producing communities in hunger and penury (see for example, Orogun, 2010). This action can be understood as an expression of distributional injustice, involving the compromised ability to access resource wealth and failure to secure livelihood and healthy environment.

To circumvent this Nigerian problem, this paper suggests that a system of effective administrative structure that would administer the fund transparently, openly and expeditiously with accountability should be established. It is assumed that the administration will be more definitive and enable each of the communities to derive optimal benefits from resource extraction within their territory. Even with all the difficulties that will no doubt plague its actual implementation as in the case of Niger Delta (Watts, 2008; Amnesty International, 2009), the administrative committee is assumed to involved, at the least, persons that are vastly transparent, accountable and superior to the status quo (Babatunde, 2012: p. 52). At best, however, it could reduce the existing cumbersome nature of man- 
aging a common fund for the communities and fundamentally improve the long-run diversification of a local economy that is largely dependent on oil extraction. NGOs, including Nigerian Extractive Industries Transparency Initiatives, should also be included in the process in order to monitor the collection, disbursement, transfer and direct distribution of revenues to the communities.

Similarly, even though environmental impact assessment (EIA) has already been legalised as part of the procedures in evaluating the consequences of any proposed mining projects in Nigeria, social impact assessment (SIA) has not yet been widely adopted in formal planning systems in Nigeria. In the same manner that EIA measures and assesses potential environmental damages, SIA assess the potential impacts of mining projects and any social change processes invoked by those projects on the communities (Esteves, 2008). Some of the benefits of SIA in mining include among others: understanding societal expectations of local benefits and promoting local community solutions, eliminate fears within the company of limitless community demands and lack of clear boundaries of responsibility, and less reliance on intuition to justify on-going social investments (Esteves, 2008: p. 346). For example, Ajayi and Ikporukpo (2005) and more recently Omotehinse and Ako (2019) noted that Jos tin and Enugu coal mines are instances of where several decades of poor mining practices and regulations have degraded the environment. However, as a result of increasing global competitiveness in mining and the need to entrench global best practices, the current Nigerian 2007 Mining Act (Minerals and Mining Regulations, 2010) provides for a very strong community relations and environmental restrictions.

As highlighted earlier, the social neglect perceived in the Niger Delta leads to the struggle for ownership of their natural resources, which created the conflicts experienced in the region. This paper is also suggesting for the integration of SIA with EIA into environmental and social impact assessment (ESIA) in a coherent and strategic manner, which would provide a platform for relevant stakeholder involvement, particularly the communities. As Esteves (2008: p. 346) noted, "SIA is an effective means of involving affected communities in problem solving and developing community goals". In the Nigerian case, this negates the existing practice of nothing more than informing the affected communities of the on-going and/or proposed plans for the area, or at the very best incorporating them as menials, assistants/informants at the preliminary stages.

Operators' compliance with laws and requirements set by the governments, borrowers or shareholders should not be the only motivation behind an all-inclusive and comprehensive stakeholder strategy. The key to success in dealing with affected communities is to view them as stakeholders rather than as a risk in business terms. It is imperative that operators understand the structure and functioning of local indigenous authority and model its initial approach on the local structure (since a one cap fits all approach does not work). Not only could this assist the company to understand their host communities, but equally important, the local people will have a much better chance of understanding the com- 
pany-if it is introduced in a term that is culturally familiar to them. The company must also keep its activities firmly anchored in the national culture of the country of operation, and take care to maintain consistency in all its policies in line with international practices. Companies that tie their fortunes to those of the surrounding region manage the risks of frontier assets better than those who do not. While the company may be seen as a surrogate government, it must be conscious of the temptation to take up the role of ineffective government, whereby decisions are made on behalf of the communities. Current social spending by extractive firms in Nigeria increases community dependence on finite resources and permits government to neglect their duty of service provisions. To stay ahead in resolving conflicting demands, operators need to be proactive, timely and transparent in their dealings.

\section{Conclusion}

The extractive industries represent an important source of global revenue for investors, communities and governments. However, this paper has demonstrated how the recognition of communities as secondary stakeholders limited their ability to derive full benefits of mineral investments within their vicinity in terms of job and business creation, infrastructural development, and long-term economic growth. It appears that the government has not meaningfully invested and protected the rights of host communities but relies on investors to do all the investments and serve as surrogate government. That will not happen, except that the government first shoulders its responsibilities before the investors play their own part. The paper concludes that unless government properly regulates the sector according to existing laws and international best practices, community problems similar to those in the oil sector are bound to happen in the non-oil sector. Also, communities should be wary of extractive industries that issue hand-outs instead of creating partnerships and cooperation. In this case, communities must be active, ambitious, and creative with their involvement in order to address their needs, get the most benefit and sustain their livelihood. Companies' investment in their host communities can only be meaningful through dialogue, understanding the community's past and desired futures, addressing real and perceived concerns, and negotiating a space for development within that vision. The paper insists that even well-meaning intentions that are not socially or environmentally grounded may be incongruous. Recognising communities as part of the major stakeholders and building dialogue and relations are crucial to ensure that they get maximum benefit from extractive activities. Therefore, exploitation of resources for the attainment of economic, social and environmental objectives of Nigeria requires attention to communities where the actual resources hit the ground. A critical examination of the way local communities demand for justice through environmental movements and social activism as well as how the companies and the government react to these struggles could provide an area for future research directions. 


\section{Dedication}

This paper is dedicated to the Co-author-Late Dr. Murtala Chindo.

\section{Conflicts of Interest}

The authors declare no conflicts of interest regarding the publication of this paper.

\section{References}

Accountability and Business for Social Responsibility (BSR) (2004). Business and Economic Development: Mining Sector Report. London: Accountability and Business for Social Responsibility.

Ajayi, D. K., \& Ikporukpo, D. C. (2005). An Analysis of Nigeria's Environmental Vision 2010. Journal of Environmental Policy and Planning, 7, 341-365. https://doi.org/10.1080/15239080500441137

Al-Abri, I., Onel, G., \& Grogan, K. A. (2019). Oil Revenue Shocks and the Growth of the Non-Oil Sector in an Oil-Dependent Economy: The Case of Oman. Theoretical Economics Letters, 9, 785-800. https://doi.org/10.4236/tel.2019.94052

Albert, I. O., Danjibo, N., \& Albert, O. (2020). Back to the Past: Evolution of Kidnapping and Hostage Taking in the Niger Delta, Nigeria. Beijing Law Review, 11, 211-226. https://doi.org/10.4236/blr.2020.111015

Albert, I. O., Olarinde, Y. T., \& Albert, O. O. (2019). Order Outside the Law? Rethinking Amnesty as an ADR Mechanism in Nigeria. Beijing Law Review, 10, 913-925. https://doi.org/10.4236/blr.2019.104049

Amare, A. (2019). Corporate Environmental Responsibility in Ethiopia: A Case Study of the Akaki River Basin. Ecosystem Health and Sustainability, 5, 57-66. https://doi.org/10.1080/20964129.2019.1573107

Amnesty International (2009). Nigeria: Petroleum, Pollution and Poverty in the Niger Delta. London: Amnesty International Publications.

Auty, R. M. (1993). Sustaining Development in Minerals Economics: The Resource Curse Thesis. London: Routledge.

Azapagic, A. (2004). Developing a Framework for Sustainable Development Indicators for the Mining and Minerals Industry. Journal of Cleaner Production, 12, 639-662. https://doi.org/10.1016/S0959-6526(03)00075-1

Babatunde, A. O. (2012). An Analytical Evaluation of the Cost of the Conflict in Nigeria's Niger Delta. Journal of Conflictology, 3, 50-58. https://doi.org/10.7238/joc.v3i1.1327

Bridge, G. (2008). Economic Geography: Natural Resources. In Kitchin, B. and Thrift, N. (Eds.), International Encyclopedia of Human Geography. Amsterdam: Elsevier.

Campbell, B. (2012). Corporate Social Responsibility and Development in Africa: Redefining the Roles and Responsibilities of Public and Private Actors in the Mining Sector. Resources Policy, 37, 138-143. https://doi.org/10.1016/j.resourpol.2011.05.002

Cheney, H., Lovel, R., \& Solomon, F. (2002). People, Power, Participation: A Study of Mining-Community Relationships. Melbourne, Australia: Mining Minerals and Sustainable Development/Australian Minerals and Energy Environment Foundation.

Chindo, M. (2011). Examining Nigerian Mining Licences and Settlements. Continental Journal of Social Sciences, 4, 46-53.

Clarkson, M. E. (1995). A Stakeholder Framework for Analyzing and Evaluating Corporate Social Performance. Academy of Management Review, 20, 92-117. 
https://doi.org/10.5465/amr.1995.9503271994

Constitution of the Federal Republic of Nigeria (1999).

Davis, G. (1998). The Mineral Sector, Sectoral Analysis, and Economic Development. Resource Policy, 24, 217-228. https://doi.org/10.1016/S0301-4207(98)00034-8

Donaldson, T., \& Preston, L. E. (1995). The Stakeholder Theory of the Corporation: Concepts, Evidence, and Implications. Academy of Management Review, 20, 65-91. https://doi.org/10.5465/amr.1995.9503271992

Edeme, R. K., \& Nkalu, N. C. (2019). Predicting the Effects of Economic Diversification on Solid Mineral Development in Nigeria. Journal of Contemporary Research in Business, Economics and Finance, 1, 56-61.

Eggert, R. (2001). MMSD Working Paper No. 19 Mining and Economic Sustainability: National Economies and Local Communities. Mining, Minerals and Sustainable Development, London: International Institute for Environment and Development.

Esteves, A. (2008). Mining and Social Development: Refocusing Community Investment and Using Multi-Criteria Decision Analysis. Resources Policy, 33, 39-47. https://doi.org/10.1016/j.resourpol.2008.01.002

Eweje, G. (2007). Multinational Oil Companies CSR Initiatives in Nigeria: The Scepticism of Stakeholders in Host Communities. Managerial Law, 49, 218-235. https://doi.org/10.1108/03090550710841340

Fell, G. (1939). The Tin Mining Industry in Nigeria. Oxford Journal of African Affairs, XXXVIII, 246-258. https://doi.org/10.1093/oxfordjournals.afraf.a101199

Fonseca, H. (Ed.) (2004). Mining: Social and Environmental Impact. World Rainforest Movement, Montevideo, Uruguay: World Rainforest Movement.

Franks, D. M., Davis, R., Bebbington, A. J., Ali, S. H., Kemp, D., \& Scurrah, M. (2014). Conflict Translates Environmental and Social Risk Into Business Costs. Proceedings of the National Academy of Sciences of the United States of America, 111, 7576-7581. http://www.pnas.org/cgi/doi/10.1073/pnas.1405135111 https://doi.org/10.1073/pnas.1405135111

Freeman, R. E. (1984). Strategic Management: A Stakeholder Approach. Boston, MA: Pitman.

Frynas, J. G. (2005). The False Developmental Promise of Corporate Social Responsibility: Evidence from Multinational Oil Companies. International Affairs, 81, 581-598. https://doi.org/10.1111/j.1468-2346.2005.00470.x

Goki, N. G., Marcus, N. D., \& Umbugadu, A. A. (2016). Preliminary Assessment of the Post-Mining Geotourism Potential of the Plateau Tin Fields, Nigeria. Acta Geoturistica, 7, 21-30.

Haysom, N., \& Kane, S. (2009). Negotiating Natural Resources for Peace: Ownership, Control and Wealth-Sharing. Geneva: HD Centre for Humanitarian Dialogue.

Hodder, B. (1959). Tin Mining on the Jos Plateau of Nigeria. Economic Geography, 35, 109-122. https://doi.org/10.2307/142394

Humphreys, D. (2000). A Business Perspective on Community Relations in Mining. Resources Policy, 26, 127-131. https://doi.org/10.1016/S0301-4207(00)00024-6

Humphreys, D. (2013). Minerals: Industry History and Fault Lines. In R. Dannreuther, \& W. Ostrowski (Eds.), Global Resources: Conflict and Cooperation (Chap. 2, pp. 33-58). Hampshire: Palgrave Macmillan. https://doi.org/10.1057/9781137349149_3

Ibrahim, H. J., \& Aliyu, S. (2010). Lead Poisoning: Story behind Zamfara Tragedy. Nigerian Best Forum, 12 June 2010. 
Idemudia, U. (2009). Oil Extraction and Poverty Reduction in the Niger Delta: A Critical Examination of Partnership Initiatives. Journal of Business Ethics, 90, 91-116. https://doi.org/10.1007/s10551-008-9916-8

International Council on Mining and Metals (ICMM) (2012). Community Development-Toolkit. London: ICMM.

International Finance Corporation (IFC) (2007). Stakeholder Engagement: A Good Practice Handbook for Companies Doing Business in Emerging Markets. Washington DC: IFC.

International Finance Corporation (IFC) Environment Division (2000). Investing in People: Sustaining Communities through Improved Business Practice. Washington DC: International Finance Corporation.

International Institute of Environment and Development (IIED) (2002). Mining, Minerals and Sustainable Development (MMSD) Report. Breaking New Grounds, Report of the MMSD Project, London: Earthscan Publications Ltd.

International Union for Conservation of Nature (2010). 118 Mining Conflicts in 15 Countries in Latin America.

http://www.iucn.org/news_homepage/news_by_date/?4651/118-mining-conflicts-in-15 -countries-in-Latin-America

Ishola, S. (2008). Federal Government Unfolds Strategies for the Development of Artisanal and Small-Scale Mining. Abuja: Ministry of Mines and Steel Development.

Jenkins, H., \& Yakovleva, N. (2006). Corporate Social Responsibility in the Mining Industry: Exploring Trends in Social and Environmental Disclosure. Journal of Cleaner Production, 14, 271-284. https://doi.org/10.1016/j.jclepro.2004.10.004

Jensen, N., \& Wantchekon, L. (2004). Resource Wealth and Political Regimes in Africa. Comparative Political Studies, 37, 816-841.

Kapelus, P. (2002). Mining, Corporate Social Responsibility and the "Community": The Case of Rio Tinto, Richards Bay Minerals and the Mbonambi. Journal of Business Ethics, 39, 275-296. https://doi.org/10.1023/A:1016570929359

Kemp, D. (2009). Mining and Community Development: Problems and Possibilities of Local-Level Practice. Community Development Journal, 45, 198-218. https://doi.org/10.1093/cdj/bsp006

Kemp, D., Owen, J. R., Gotzmann, N., \& Bond, C. J. (2011). Just Relations and Company-Community Conflict in Mining. Journal of Business Ethics, 101, 93-109. https://doi.org/10.1007/s10551-010-0711-y

Koos, C., \& Pierskalla, J. (2016). The Effects of Oil Production and Ethnic Representation on Violent Conflict in Nigeria: A Mixed-Methods Approach. Terrorism and Political Violence, 28, 888-911. https://doi.org/10.1080/09546553.2014.962021

Li, Z. X., Nieto, A., Zhao, Y. Q., Cao, Z. G., \& Zhao, H. Y. (2012). Assessment Tools, Prevailing Issues and Policy Implications of Mining Community Sustainability in China. International Journal of Mining, Reclamation and Environment, 26, 148-162. https://doi.org/10.1080/17480930.2011.593351

Luning, S. (2012). Corporate Social Responsibility (CSR) for Exploration: Consultants, Companies and Communities in Processes of Engagements. Resource Policy, 37, 205-211. https://doi.org/10.1016/j.resourpol.2011.02.004

Maconachie, R., \& Hilson, G. (2013). Editorial Introduction: The Extractive Industries, Community Development and Livelihood Change in Developing Countries. Community Development Journal, 48, 347-359. https://doi.org/10.1093/cdj/bst018

Marcellus, I. O. (2010). The Imperative of Integrated Mineral and Oil Resources Extrac- 
tion and Management Policy for Sustainable Peace and Development in Nigeria. Journal of Environmental Assessment Policy and Management, 12, 51-68. https://doi.org/10.1142/S1464333210003516

Matu, J., Kyalo, D., Mbugua, J., \& Mulwa, A. (2020). Stakeholder Participation in Project Planning: Prerequisite to Effective Completion of Urban Road Transport Infrastructure Projects in Kenya. Journal of Building Construction and Planning Research, 8, 73-91. https://doi.org/10.4236/jbcpr.2020.81006

Minerals and Mining Regulations (2010). Minerals and Mining Regulations. Abuja: Ministry of Mines and Steel Development.

Ministry of Mines and Steel Development (MSMD) (2008). About Ministry of Mines and Steel Development. Abuja: MSMD.

Muradian, R., Martinez-Alier, J., \& Correa, H. (2003). International Capital versus Local Population: The Environmental Conflict of the Tambogrande Mining Project, Peru. Society and Natural Resources, 16, 775-792. https://doi.org/10.1080/08941920309166

National Bureau of Statistics (2008). Facts and Figures 2007. Abuja: NBS Headquarters.

Ogunleye, E. K. (2008). Natural Resource Abundance in Nigeria: From Dependence to Development. Resources Policy, 33, 168-174. https://doi.org/10.1016/j.resourpol.2008.03.002

Ojo, G. U. (2012). Economic Diversification and Second-Tier Political Conflict: Assessing Bitumen Political Ecologies in Southwest Nigeria. Singapore Journal of Tropical Geography, 33, 49-62. https://doi.org/10.1111/j.1467-9493.2012.00447.x

Omotehinse, A. O., \& Ako, B. D. (2019). The Environmental Implications of the Exploration and Exploitation of Solid Minerals in Nigeria with a Special Focus on Tin in Jos and Coal in Enugu. Journal of Sustainable Mining, 18, 18-24.

https://doi.org/10.1016/j.jsm.2018.12.001

Orogun, P. S. (2010). Resource Control, Revenue Allocation and Petroleum Politics in Nigeria: The Niger Delta Question. GeoJournal, 75, 459-507.

https://doi.org/10.1007/s10708-009-9320-7

Östensson, O. (1997). A Brief Background on Social Issues and Mining. UNCTAD (United Nations Conference on Trade and Development), The Asian/Pacific Workshop on Managing the Social Impacts of Mining, Bandung, Indonesia, 14-15 October 1996.

Phillips, R. A., \& Reichart, J. (2000). The Environment as a Stakeholder? A Fairness-Based Approach. Journal of Business Ethics, 23, 185-197. https://doi.org/10.1023/A:1006041929249

Salim, E. (2003). Extractive Industries Review, Striking a Better Balance. Washington DC: International Finance Corporation and the World Bank.

United Nations Development Programme (UNDP) (2006). Niger Delta Human Development Report. Abuja: Perfect Printer.

United Nations Environmental Programme (UNEP) (2011). Environmental assesSment of Ogoniland. Nairobi: United Nations Environment Programme.

Usman, N. (2001). Environmental Regulation in the Nigerian Mining Industry: Past, Present and Future. Journal of Energy and Natural Resources Law, 19, 230-243. https://doi.org/10.1080/02646811.2001.11433232

Vanguard (2010). Mining Activities Threaten MDGs in Plateau. Vanguard Online Edition, 25 August 2010.

Veiga, M. M., Scoble, M., \& McAllister, M. L. (2001). Mining with Communities. Natural Resources Forum, 25, 191-202. https://doi.org/10.1111/j.1477-8947.2001.tb00761.x

Watts, M. (2004a). Resource Curse? Governmentality, Oil and Power in the Niger Delta, 
Nigeria. Geopolitics, 9, 50-80. https://doi.org/10.1080/14650040412331307832

Watts, M. (2004b). Violent Environment: Petroleum Conflict and the Political Ecology of Rule in the Niger Delta. In R. Peet, \& M. Watts (Eds.), Liberation Ecologies: Environment, Development, Social Movements (2nd ed., Part IV, pp. 273-298). East Sussex: Psychology Press.

Watts, M. (Ed.) (2008). Curse of the Black Gold. 50 Years of Oil in the Niger Delta. New York: Powerhouse Books. 